\title{
Synergistic increase in the sensitivity of osteosarcoma cells to thermochemotherapy with combination of paclitaxel and etoposide
}

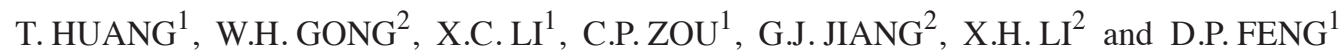 \\ ${ }^{1}$ Department of Orthopedics, The First Affiliated Hospital of China Medical University, Shenyang, Liaoning 110001, \\ P.R. China; ${ }^{2}$ Beth Israel Deaconess Medical Center, Harvard Medical School, Boston, MA 02215, USA
}

Received March 25, 2012; Accepted August 6, 2012

DOI: $10.3892 / \mathrm{mmr} .2012 .1058$

\begin{abstract}
Osteosarcoma is a malignant bone tumor which is found most commonly in adolescents and young adults. Local perfusion thermochemotherapy has long been proposed as an alternative strategy for the treatment of osteosarcoma. As a standard anticancer drug, paclitaxel plays a significant role in the treatment of a number of tumors; however, little is known concerning its ability to promote thermochemotherapy. The aim of this study was to evaluate the cytotoxic effects of a combination of paclitaxel and etoposide on an osteosarcoma cell line in the presence of hyperthermia and to investigate the related mechanism. Our study indicated that $1 \mathrm{~h}$ after the application of a combination of $10 \mu \mathrm{g} / \mathrm{ml}$ paclitaxel and $5 \mu \mathrm{g} / \mathrm{ml}$ etoposide to OS732 cells at $43^{\circ} \mathrm{C}$, the survival rate of the cells was $14.52 \%$ which was significantly lower than when either $10 \mu \mathrm{g} / \mathrm{ml}$ paclitaxel $(45.83 \%)$ or $5 \mu \mathrm{g} / \mathrm{ml}$ etoposide $(43.31 \%)$ was applied alone $(\mathrm{P}<0.01)$. Moreover, changes in cellular morphology and apoptotic rates indicated that the apoptosis-inducing effect of the combination was much stronger than that of either drug applied individually. Fas expression levels in the OS732 cells were increased by the combination of paclitaxel and etoposide in the presence of hyperthermia. Therefore, paclitaxel enhances the thermochemotherapy of the osteosarcoma cell line and this is primarily accomplished by the upregulation of Fas expression and the induction of apoptosis.
\end{abstract}

\section{Introduction}

Osteosarcoma is an aggressive malignant neoplasm with poor prognosis. The use of local excision of the tumor tissue with limb salvage surgery combined with neoadjuvant chemotherapy has improved the survival rate markedly $(1,2)$.

Correspondence to: Dr Tao Huang, Department of Orthopedics, The First Affiliated Hospital of China Medical University, 115 Nanjing Street, Shenyang, Liaoning 110001, P.R. China E-mail: huangtao@mail.cmu.edu.cn

Key words: thermochemotherapy, paclitaxel, etoposide, osteosarcoma
However, the local excision is not always complete, which triggers recurrence at the primary site, leading to treatment failure $(3,4)$. Local perfusion thermochemotherapy has long been proposed as an anticancer treatment, specifically for the prevention of local recurrence, for use in combination with surgery and chemotherapy (5-7). It has been shown that, at high temperatures, chemotherapeutic drugs kill the osteosarcoma tumor tissue that has not been removed by surgery, thereby reducing recurrence at the primary site $(8,9)$.

Our laboratory has focused on identifying strategies for improving the thermochemotherapeutic effect of etoposide on osteosarcoma. We hypothesized that the combination of paclitaxel and etoposide in the presence of hyperthermia is likely to have an improved killing effect on osteosarcoma cells. The purpose of this study was to evaluate the cytotoxic effects of a combination of paclitaxel and etoposide on an osteosarcoma cell line in the presence of hyperthermia and investigate the effects of the combination on the Fas-associated death receptor pathway.

\section{Materials and methods}

Materials. The OS732 osteosarcoma cell line was bought from Beijing Jishuitan Hospital and the RPMI-1640 powder was acquired from Gibco-BRL (Carlsbad, CA, USA). Trypsin, MTT and RNase A were acquired from Huamei Biological Co. (Beijing, China). The following materials were also used: paclitaxel (Beijing Concord Pharmaceutical, Beijing, China), etoposide (Hisun Pharmaceutical Co., Zhejiang, China), an enzyme meter (Bio-Rad, Hercules, CA, USA), a FACScan flow cytometer (Becton-Dickinson, Franklin Lakes, NJ, USA), an LH50A inverted phase contrast microscope (Olympus, Tokyo, Japan) and a fluorescence microscope (Nikon, Tokyo, Japan).

Cell culture and research methods. The OS732 osteosarcoma cell line was added to RMPI-1640 solution with $10 \%$ fetal bovine serum and cultured in an incubator at $37^{\circ} \mathrm{C}$ in a humidified 5\% $\mathrm{CO}_{2}$ atmosphere. The cells that had entered the logarithmic growth phase were selected and heated using a numerical display constant temperature $\left( \pm 0.1^{\circ} \mathrm{C}\right)$ water bath, set at various temperatures $\left(37,40\right.$ and $\left.43^{\circ} \mathrm{C}\right)$ for $1 \mathrm{~h}$. We selected concentrations of $1,10,50$ and $100 \mu \mathrm{g} / \mathrm{ml}$ for the paclitaxel group, 1, 5, 10 and $100 \mu \mathrm{g} / \mathrm{ml}$ for the etoposide 
group and $10 \mu \mathrm{g} / \mathrm{ml}$ paclitaxel with $5 \mu \mathrm{g} / \mathrm{ml}$ etoposide for the combination group. PBS was used for the blank control group. These concentrations were selected on the basis of $\mathrm{EC}_{50}$ doses that we established in a preliminary trial. All trials were repeated four times. The study was approved by the ethics committee of China Medical University.

Measurement of the survival rates of tumor cells by the MTT method. The treated cells $\left(5 \times 10^{5} / \mathrm{ml}\right)$ were seeded in a 96-well plate with a $200 \mu 1$ reaction volume per well, using 4 parallel wells per group. After culturing for $24 \mathrm{~h}$, freshly prepared $5 \mathrm{mg} / \mathrm{ml}$ MTT was added to each well and incubation was continued at $37^{\circ} \mathrm{C}$ for $4 \mathrm{~h}$. The supernatant was then discarded and $150 \mu \mathrm{l}$ DMSO was added. The absorbance (A) was measured at $540 \mathrm{~nm}$. The survival rate of the tumor cells $(\%)=\mathrm{A}_{\text {experimental group }} / \mathrm{A}_{\text {control group }} \times 100$.

Observation of the morphology of apoptotic cells. The morphology, number and adherence of the tumor cells were directly observed using an inverted phase contrast microscope. A cover slide was placed in a 6-well plate, seeded with OS732 cells, fixed for $10 \mathrm{~min}$ and stained with $0.5 \mathrm{ml}$ Hoechst 33258 staining solution for $5 \mathrm{~min}$. Images were then captured using a fluorescence microscope.

Measurement of the proportion of apoptotic cells by flow cytometry (FCM). The digested cells were collected, washed with PBS, centrifuged and then treated with $70 \%$ cold ethanol to fix overnight. The cells were then centrifuged to remove ethanol and washed twice with PBS. The cells were stained in the dark with $100 \mu \mathrm{l}$ PI staining solution at $4^{\circ} \mathrm{C}$ for $1 \mathrm{~h}$. The strength of the fluorescence was measured using a FACScan flow cytometer. The wavelength of the activating light was $488 \mathrm{~nm}$, and the apoptotic rates were measured using CellQuest analysis software.

Immunocytochemistry to detect Fas expression in OS732 cells. Digested cells $\left(2 \times 10^{5} / \mathrm{ml}\right)$ were placed in a 6-well culture plate with a pre-treated cover slide in each well. After culturing for $24 \mathrm{~h}$, the supernatants were discarded, the drug or drug combination was added and culturing was continued for $24 \mathrm{~h}$. A blank control group was also established. The cover slides were removed, fixed with acetone at $4^{\circ} \mathrm{C}$ for $10 \mathrm{~min}$ and stained by the SP method. A brown-yellow cytoplasm indicated a Fas-positive cell, and the expression levels of Fas were determined from the average gray levels obtained using a micro-picture analysis system.

Statistic method. Experimental data are the mean \pm SD. Comparisons among groups were made by ANOVA, and for any two groups, a t-test was used for statistical analysis. $\mathrm{P}<0.05$ was considered to indicate a statistically significant result. All results were analyzed using Windows SPSS 15.0 software.

\section{Results}

Changes in the survival rates of the tumor cells for the three thermochemotherapeutic drug treatments. Following the treatment of the OS732 cells at various temperatures for $1 \mathrm{~h}$ with paclitaxel at concentrations of $1,10,50$ and $100 \mu \mathrm{g} / \mathrm{ml}$,
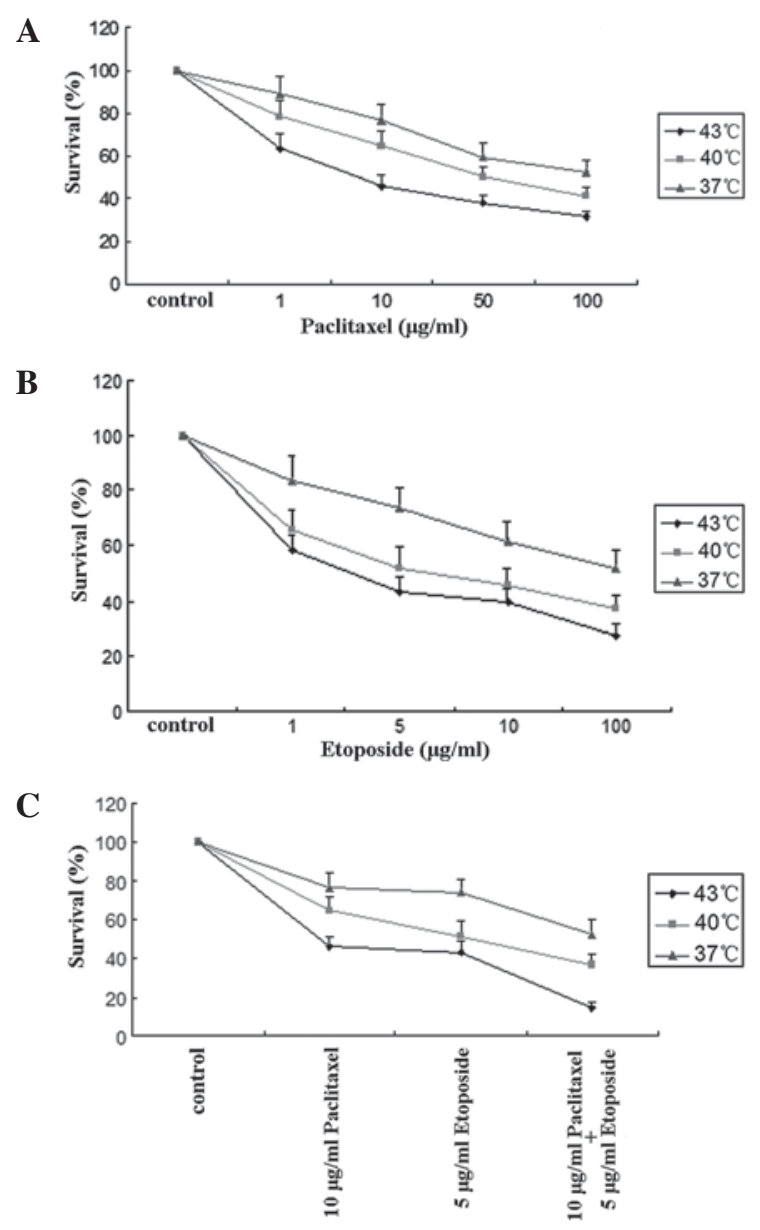

Figure 1. The inhibitory effects of chemotherapeutic agents on OS732 cells treated at various temperatures for $1 \mathrm{~h}$, measured by MTT. Survival rates of OS732 cells treated with (A) various concentrations of paclitaxel, (B) various concentrations of etoposide and (C) a combination of $10 \mu \mathrm{g} / \mathrm{ml}$ paclitaxel and $5 \mu \mathrm{g} / \mathrm{ml}$ etoposide.

the cell growth was inhibited in a dose-dependent manner and there were significant differences between the groups $(\mathrm{P}<0.05$; Fig. 1A). Similarly, when etoposide was used at concentrations of $1,5,10$ and $100 \mu \mathrm{g} / \mathrm{ml}$, the cell growth also varied between the groups $(\mathrm{P}<0.05$; Fig. 1B). For the combination of $10 \mu \mathrm{g} / \mathrm{ml}$ paclitaxel and $5 \mu \mathrm{g} / \mathrm{ml}$ etoposide, the survival rate was significantly lower $(\mathrm{P}<0.01$; Fig. $1 \mathrm{C})$ than for either $10 \mu \mathrm{g} / \mathrm{ml}$ paclitaxel or $5 \mu \mathrm{g} / \mathrm{ml}$ etoposide alone, showing that the combination of paclitaxel and etoposide has a stronger inhibitory effect than either single agent. More significantly, we found that the cell growth was inhibited in a temperaturedependent manner since the survival rates of the OS732 cells were lowest at $43^{\circ} \mathrm{C}$ and highest at $37^{\circ} \mathrm{C}$.

Morphological changes of apoptosis in OS732 cells. Under an inverted phase contrast microscope, the normal OS732 cells were observed to be attached to the dish; the cells were rhomboid and angular and were growing adhered to the dish (Fig. 2A). Following the application of either paclitaxel $(10 \mu \mathrm{g} / \mathrm{ml})$ or etoposide $(5 \mu \mathrm{g} / \mathrm{ml})$, certain parts of the cells became small and round (Fig. 2B and C) whereas following the combined application, chromatin and cytoplasm condensation occurred and numerous cells exfoliated and were suspended in 


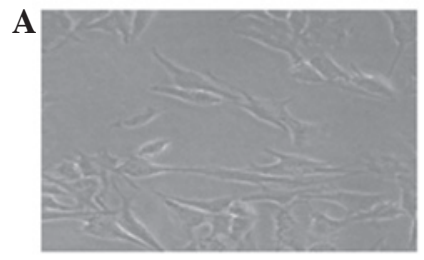

Control

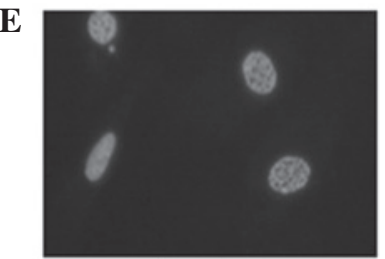

Control

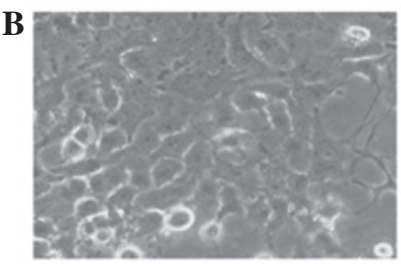

Paclitaxel

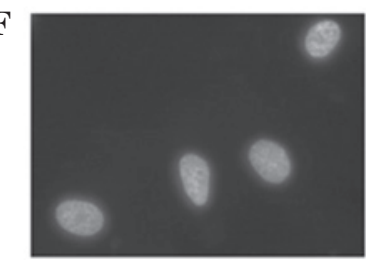

Paclitaxel

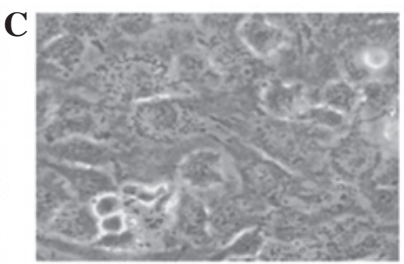

Etoposide

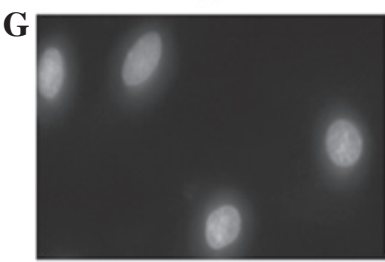

Etoposide

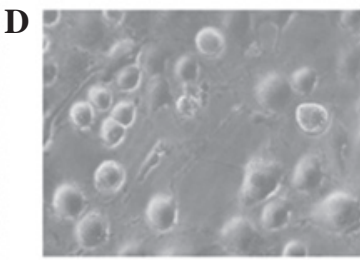

Pac+Eto

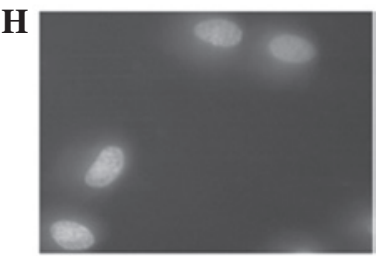

Pac+Eto

Figure 2. Morphological changes and fluorescent staining of OS732 cells treated with various drugs at $43^{\circ} \mathrm{C}$ for $1 \mathrm{~h}$. Morphological appearance of (A) control OS732 cells, (B) OS732 cells treated with $10 \mu \mathrm{g} / \mathrm{ml}$ paclitaxel, (C) OS732 cells treated with $5 \mu \mathrm{g} / \mathrm{ml}$ etoposide and (D) OS732 cells treated with a combination of $10 \mu \mathrm{g} / \mathrm{ml}$ paclitaxel and $5 \mu \mathrm{g} / \mathrm{ml}$ etoposide viewed under an inverted phase contrast microscope (x400). Fluorescent staining of (E) control OS732 cells, (F) OS732 cells treated with $10 \mu \mathrm{g} / \mathrm{ml}$ paclitaxel, (G) OS732 cells treated with $5 \mu \mathrm{g} / \mathrm{ml}$ etoposide and (H) OS732 cells treated with $10 \mu \mathrm{g} / \mathrm{ml}$ paclitaxel and $5 \mu \mathrm{g} / \mathrm{ml}$ etoposide viewed under a fluorescence microscope $(\mathrm{x} 400)$.

A

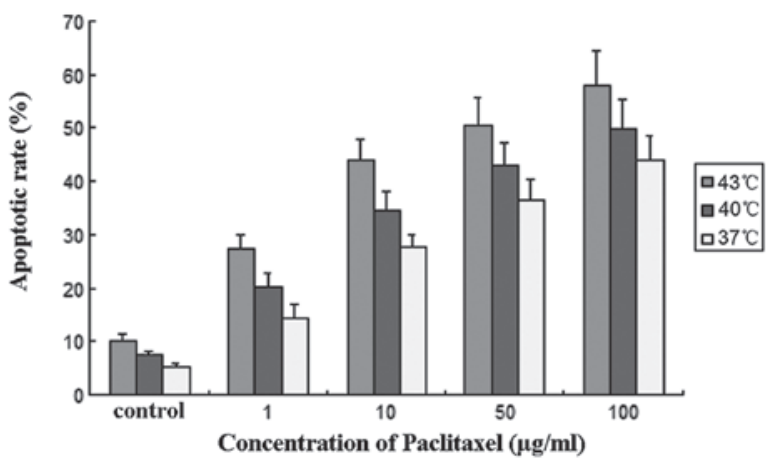

B
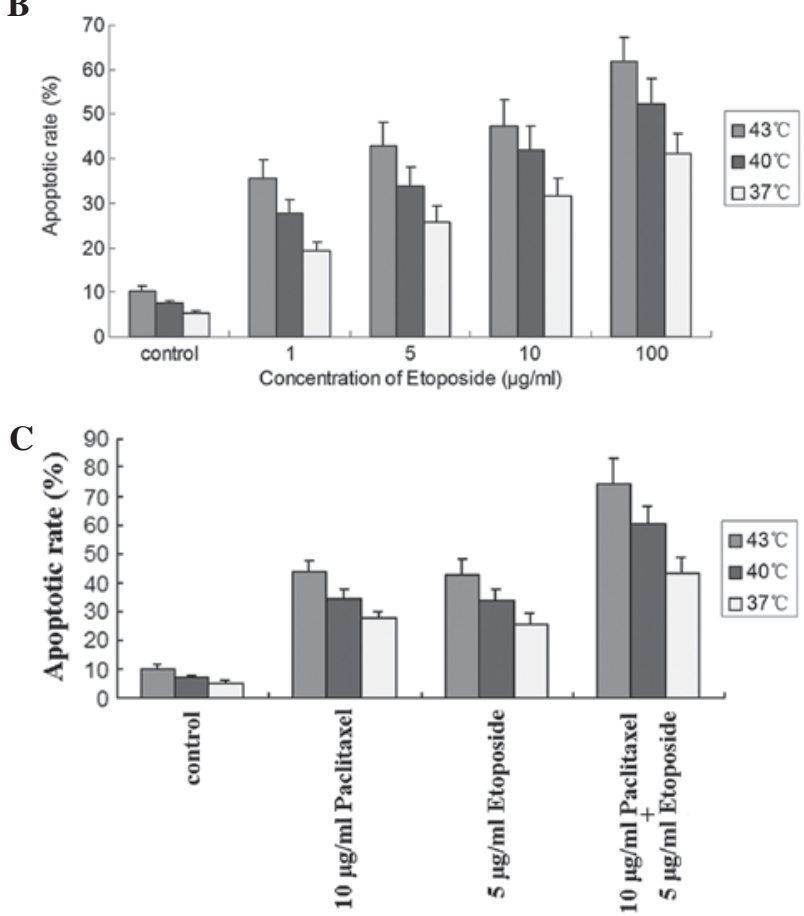

Figure 3. Apoptotic effect in OS732 cells of drug treatment at various temperatures for $1 \mathrm{~h}$. Apoptotic rates in OS732 cells treated with (A) various concentrations of paclitaxel, (B) various concentrations of etoposide and (C) a combination of $10 \mu \mathrm{g} / \mathrm{ml}$ paclitaxel and $5 \mu \mathrm{g} / \mathrm{ml}$ etoposide. the culture medium (Fig. 2D). Using a fluorescence microscope, lightly-stained control OS732 cells were observed (Fig. 2E). Following the application of either paclitaxel $(10 \mu \mathrm{g} / \mathrm{ml})$ or etoposide $(5 \mu \mathrm{g} / \mathrm{ml})$, only parts of the cells demonstrated condensed and flared fluorescence (Fig. 2F and G) whereas, following the combined application, condensed and flared fluorescence was clearly observed, revealing the presence of numerous apoptotic cells (Fig. 2H).

Comparison of the apoptotic rates in OS732 cells for various medication methods by FCM. Following the treatment of the cells at various temperatures for $1 \mathrm{~h}$ with paclitaxel at concentrations of $1,10,50$ and $100 \mu \mathrm{g} / \mathrm{ml}$, the apoptotic rate increased in a dose-dependent manner and there were significant differences between the groups $(\mathrm{P}<0.05$; Fig. 3A). For etoposide concentrations of $1,5,10$ and $100 \mu \mathrm{g} / \mathrm{ml}$, the apoptotic rate also increased in a dose-dependent manner, and there were significant differences between groups $(\mathrm{P}<0.01$; Fig. 3B). For the combination of $10 \mu \mathrm{g} / \mathrm{ml}$ paclitaxel and $5 \mu \mathrm{g} / \mathrm{ml}$ etoposide, the apoptotic rate was significantly higher $(\mathrm{P}<0.01$; Fig. $3 \mathrm{C})$ than for $10 \mu \mathrm{g} / \mathrm{ml}$ paclitaxel or $5 \mu \mathrm{g} / \mathrm{ml}$ etoposide alone, indicating that the combined use of paclitaxel and etoposide has a stronger apoptosis-inducing effect than the use of either individually.

Fas expression in OS732 cells by immunocytochemistry. We observed only a small number of brown particles in the cytoplasms of the control OS732 cells (Fig. 4A). Deeper staining of the cytoplasms was observed following treatment with $10 \mu \mathrm{g} / \mathrm{ml}$ paclitaxel (Fig. 4B) or $5 \mu \mathrm{g} / \mathrm{ml}$ etoposide (Fig. 4C). For cells treated with a combination of $10 \mu \mathrm{g} / \mathrm{ml}$ paclitaxel and $5 \mu \mathrm{g} / \mathrm{ml}$ etoposide, the cytoplasms were stained much more strongly; staining was observed in the entire field of vision (Fig. 4D). We further measured the Fas levels quantitatively using a MetaMorph automatic image analyzer to compare the average gray values, which are inversely proportional to the levels of Fas expression (Fig. 4E) 


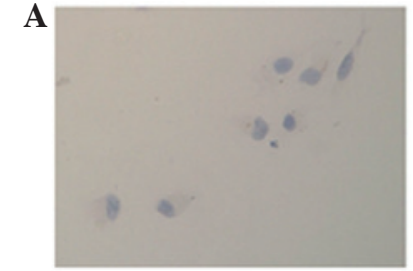

Control

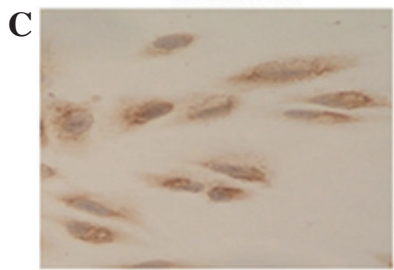

Etoposide

$\mathbf{E}$

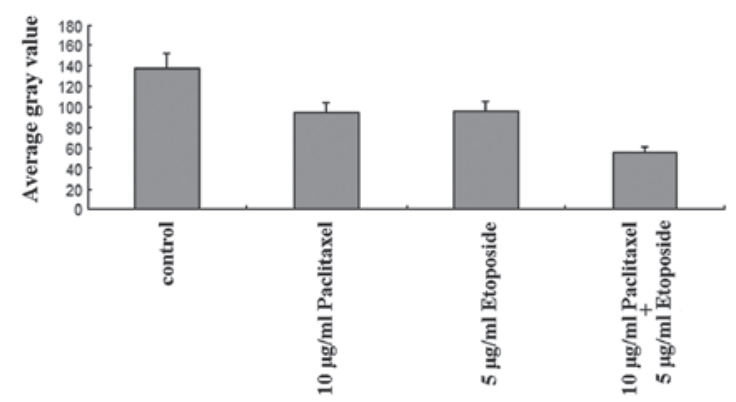

Figure 4. Fas expression in OS732 cells following treatment with various drugs at $43^{\circ} \mathrm{C}$ for $1 \mathrm{~h}$. Fas expression in (A) control OS732 cells, (B) OS732 cells treated with $10 \mu \mathrm{g} / \mathrm{ml}$ paclitaxel, (C) OS732 cells treated with $5 \mu \mathrm{g} / \mathrm{ml}$ etoposide and (D) OS732 cells treated with a combination of $10 \mu \mathrm{g} / \mathrm{ml} \mathrm{pacli-}$ taxel and $5 \mu \mathrm{g} / \mathrm{ml}$ etoposide, visualized by immunocytochemical staining (x400). (E) Fas levels in OS732 cells following various treatments, determined by comparison of average gray values obtained using a micro-picture analysis system.

\section{Discussion}

Thermochemotherapy is a comprehensive method that has been developed based on the hyperthermal therapy of malignant tumors. The isolated perfused chemotherapy of osteosarcoma hyperthermally may not only effectively control the primary local tumor, but also greatly increase the rate of successful limb salvage $(6,8)$. Although the efficacy of thermotherapy with etoposide has been extensively demonstrated in a number of tumor tissues (10-12), there are only limited studies available in the field of osteosarcoma. It is well known that the optimal therapeutic temperature clinically is $42-43^{\circ} \mathrm{C}$ for $1 \mathrm{~h}(10)$ as this maximizes the tumor damage while preserving the surrounding normal tissue. We also found that $43^{\circ} \mathrm{C}$ is the ideal temperature for a combination of paclitaxel and etoposide to kill the OS732 cell lines in thermochemotherapy.

In the current study, we found that following the use of etoposide or paclitaxel at various temperatures for $1 \mathrm{~h}$, the proliferation of tumor cells was inhibited in a dose-dependent manner, indicating that each drug had a characteristic thermotherapy-enhanced effect (Fig. 1A and B). From observation of the morphological changes in the apoptotic cells by inverted phase contrast microscopy (Fig. 2B and C) and by fluorescence microscopy (Fig. $2 \mathrm{~F}$ and G), we deduced that paclitaxel and etoposide induced apoptosis in the osteosarcoma cells.
Assessment of the proportion of apoptotic cells by FCM (Fig. 3A and B) revealed that the killing effect on OS732 cells was due to the induction of apoptosis.

Currently, there is a consensus on the enhancing effect of thermotherapy on etoposide (10-12), and positive views on the enhancing effect of thermotherapy on paclitaxel have been reported (13-15). However, there are also contrary opinions; Mohamed et al reported that the cytotoxicity of docetaxel is enhanced by hyperthermia whereas that of paclitaxel is not (16).

We found that following the joint application of low doses of paclitaxel and etoposide to OS732 cells at $43^{\circ} \mathrm{C}$ for $1 \mathrm{~h}$, the cell survival rates decreased sharply compared with those treated individually with paclitaxel or etoposide (Fig. 1C), demonstrating that the combined use of paclitaxel and etoposide has a stronger inhibitory effect. We also found apoptotic changes in the combination group when observing the cells under an inverted phase contrast microscope (Fig. 2D) as well as with a fluorescence microscope (Fig. $2 \mathrm{H}$ ). The apoptotic rates in the combination group were clearly higher $(\mathrm{P}<0.01)$ than in the individual treatment groups, indicating that the inhibitory effect on the tumor cells was predominantly accomplished by the induction of apoptosis (Fig. 3C), in agreement with studies in other tumors (17).

There are two accepted theories concerning the antitumor mechanism of thermochemotherapy. Firstly, thermotherapy may alter the membranes of the tumor cells and thereby enable the drugs to enter the tumor cells more easily (18). Secondly, thermotherapy may promote the ability of the drugs to induce apoptosis in the tumor cells. A number of chemotherapeutic agents induce cellular apoptosis by various mechanisms which may be promoted by thermotherapy. Our study indicates that, under hyperthermal conditions, paclitaxol and etoposide each individually increased Fas expression levels compared with the control group; however, the combination of paclitaxel and etoposide greatly increased the Fas expression levels in the OS732 cells compared with the individual treatments (Fig. 4).

Previous studies have revealed that Fas-FADD signaling is critical in the induction of apotosis in tumor cells by etoposide (19-21). Our results are essentially consistent with those of previous studies. As for the antitumor mechanism of paclitaxel, it is primarily regarded to be the induction of cell accumulation in the G2/M phase of the cell cycle (22). Certain studies have revealed that Fas-FADD signaling is also influential in the induction of apoptosis in tumor cells by paclitaxel $(23,24)$. It has also been reported that paclitaxel triggers cell death in H460 cells via an unidentified caspase-independent mechanism (25). Our results reveal that paclitaxel increases the expression levels of Fas in OS732 cells; however, we should not neglect the possibility that hyperthermia is also involved in the upregulation of Fas expression since previous studies have indicated that hyperthermia affects Fas levels $(26,27)$. We found that, in the presence of hyperthermia, small doses of paclitaxel and etoposide synergistically contributed to the upregulation of Fas, which we reveal is the probable mechanism by which paclitaxel acts in the thermochemotherapy of osteosarcoma. Since local thermal etoposide infusion chemotherapy has been widely used clinically, we expect that the upregulation of Fas is likely to help to improve the sensitivity of the osteosarcoma cells to thermochemotherapy with etoposide and maximize 
the cytotoxic effects on the primary tumor so as to prevent recurrence following surgery.

In conclusion, our results demonstrate that paclitaxel is capable of sensitizing the OS732 cell line to etoposide in the presence of hyperthermia by upregulation of Fas expression. Paclitaxel is commonly used in cancer treatment $(28,29)$. However, we consider that the use of paclitaxel in the thermochemotherapy of osteosarcoma would be a more suitable therapeutic method. Since etoposide and paclitaxel are antitumor drugs with specific therapeutic effects, toxicity and resistance may readily occur following their large-dose and long-term use, whereas the combined application of small doses of etoposide and paclitaxel in the presence of hyperthermia is likely to enhance the apoptosis-inducing effect, resulting in improved drug sensitivity in osteosarcoma patients and minimizing the cytotoxicity caused by clinical chemotherapy.

In this study, the combined application of $10 \mu \mathrm{g} / \mathrm{ml} \mathrm{pacli-}$ taxel and $5 \mu \mathrm{g} / \mathrm{ml}$ etoposide to OS732 cells in the presence of hyperthermia greatly inhibited the OS732 cells by inducing apoptosis more strongly than the application of $10 \mu \mathrm{g} / \mathrm{ml}$ paclitaxel or $5 \mu \mathrm{g} / \mathrm{ml}$ etoposide alone. Paclitaxel enhances the thermochemotherapy of osteosarcoma cell lines and this is primarily accomplished by the upregulation of Fas expression and the induction of apoptosis.

\section{Acknowledgements}

This article was checked by Dr Shavali Shaik of Beth Israel Deaconess Medical Center, Harvard Medical School.

\section{References}

1. Bacci G, Balladelli A, Palmerini E, et al: Neoadjuvant chemotherapy for osteosarcoma of the extremities in preadolescent patients: the Rizzoli Institute experience. J Pediatr Hematol Oncol 30: 908-912, 2008.

2. Bacci G, Rocca M, Salone M, et al: High grade osteosarcoma of the extremities with lung metastases at presentation: treatment with neoadjuvant chemotherapy and simultaneous resection of primary andmetastatic lesions. J Surg Oncol 98: 415-420, 2008.

3. Franke M, Hardes J, Helmke K, et al: Solitary skeletal osteosarcoma recurrence. Findings from the Cooperative Osteosarcoma Study Group. Pediatr Blood Cancer 56: 771-776, 2011.

4. Andreou D, Bielack SS, Carrle D, et al: The influence of tumor- and treatment-related factors on the development of local recurrence in osteosarcoma after adequate surgery. An analysis of 1355 patients treated on neoadjuvant Cooperative Osteosarcoma Study Group protocols. Ann Oncol 22: 1228-1235, 2011

5. Routt SM, Zhu J, Zaleski JM and Dynlacht JR: Potentiation of metalloenediyne cytotoxicity by hyperthermia. Int J Hyperthermia 27: 435-444, 2011.

6. Streckfus CF, Brown RE and Bull JM: Proteomics, morphoproteomics, saliva and breast cancer: an emerging approach to guide the delivery of individualised thermal therapy, thermochemotherapy and monitor therapy response. Int J Hyperthermia 26: 649-661, 2010

7. Trieb K, Blahovec $\mathrm{H}$ and Kubista B: Effects of hyperthermia on heat shock protein expression, alkaline phosphatase activity and proliferation in human osteosarcoma cells. Cell Biochem Funct 25: 669-672, 2007.

8. Fan QY, Ma BA, Zhou Y, et al: Bone tumors of the extremities or pelvis treated by microwave-induced hyperthermia. Clin Orthop Relat Res 406: 165-175, 2003.
9. Shido Y, Nishida Y, Suzuki Y, et al: Targeted hyperthermia using magnetite cationic liposomes and an alternating magnetic field in a mouse osteosarcoma model. J Bone Joint Surg Br 92: 580-585, 2010.

10. Vujaskovic Z, Kim DW, Jones E, et al: A phase I/II study of neoadjuvant liposomal doxorubicin, paclitaxel, and hyperthermia in locally advanced breast cancer. Int J Hyperthermia 26: 514-521, 2010.

11. Tang Y and McGoron AJ: Combined effects of laser-ICG photothermotherapy and doxorubicin chemotherapy on ovarian cancer cells. J Photochem Photobiol B 97: 138-144, 2009.

12. Fiorillo A, DeRosa G, Giugliano F, et al: Efficacy of pegylated lyposomal anthracyclines and of intra-arterial carboplatin and doxorubicin combined with local hyperthermia in a case of malignant endovascular papillary angioendothelioma. Curr Drug Deliv 6: 58-61, 2009.

13. Liu B, Yang M, Li X, et al: Enhanced efficiency of thermally targeted taxanes delivery in a human xenograft model of gastric cancer. J Pharm Sci 97: 3170-3181, 2008.

14. Michalakis J, Georgatos SD, de Bree E, et al: Short-term exposure of cancer cells to micromolar doses of paclitaxel, with or without hyperthermia, induces long-term inhibition of cell proliferation and cell death in vitro. Ann Surg Oncol 14: 1220-1228, 2007.

15. Zoul Z, Filip S, Melichar B, et al: Weekly paclitaxel combined with local hyperthermia in the therapy of breast cancer locally recurrent after mastectomy - a pilot experience. Onkologie 27: 385-388, 2004

16. Mohamed F, Marchettini P, Stuart OA, et al: Thermal enhancement of new chemotherapeutic agents at moderate hyperthermia. Ann Surg Oncol 10: 463-468, 2003.

17. de Bree E, Theodoropoulos PA, Rosing H, et al: Treatment of ovarian cancer using intraperitoneal chemotherapy with taxanes: from laboratory bench to bedside (Review). Cancer Treat Rev 32: 471-482, 2006

18. de Bree E, Rosing H, Michalakis J, et al: Intraperitoneal chemotherapy with taxanes for ovarian cancer with peritoneal dissemination (Review). Eur J Surg Oncol 32: 666-670, 2006.

19. Miyata S, Takemura G, Kosai K, et al: Anti-Fas gene therapy prevents doxorubicin-induced acute cardiotoxicity through mechanisms independent of apoptosis. Am J Pathol 176: 687-698, 2010

20. Kim HS, Lee YS and Kim DK: Doxorubicin exerts cytotoxic effects through cell cycle arrest and Fas-mediated cell death. Pharmacology 84: 300-309, 2009.

21. Li S, Zhou Y, Dong Y and Ip C: Doxorubicin and selenium cooperatively induce Fas signaling in the absence of Fas/Fas ligand interaction. Anticancer Res 27: 3075-3082, 2007.

22. Drago-Ferrante R, Santulli A, Di Fiore R, et al: Low doses of paclitaxel potently induce apoptosis in human retinoblastoma Y79 cells by up-regulating E2F1. Int J Oncol 33: 677-687, 2008.

23. Pires NM, Eefting D, de Vries MR, et al: Sirolimus and paclitaxel provoke different vascular pathological responses after local delivery in a murine model for restenosis on underlying atherosclerotic arteries. Heart 93: 922-927, 2007.

24. Stumm S, Meyer A, Lindner M, et al: Paclitaxel treatment of breast cancer cell lines modulates Fas/Fas ligand expression and induces apoptosis which can be inhibited through the CD40 receptor. Oncology 66: 101-111, 2004.

25. Huisman C, Ferreira CG, Bröker LE, et al: Paclitaxel triggers cell death primarily via caspase-independent routes in the non-small cell lung cancer cell line NCI-H460. Clin Cancer Res 8: 596-606, 2002.

26. Wang X, Gao XH, Li X, et al: Local hyperthermia induces apoptosis of keratinocytes in both normal skin and condyloma acuminata via different pathways. Apoptosis 14: 721-728, 2009.

27. Yu DY, Matsuya Y,Zhao QL, et al: Enhancement of hyperthermiainduced apoptosis by a new synthesized class of furan-fused tetracyclic compounds. Apoptosis 12: 1523-1532, 2007.

28. Ohguri T, Imada H, Narisada H, et al: Systemic chemotherapy using paclitaxel and carboplatin plus regional hyperthermia and hyperbaric oxygen treatment for non-small cell lung cancer with multiple pulmonary metastases: preliminary results. Int $\mathrm{J}$ Hyperthermia 25: 160-167, 2009.

29. Hulshof MC, Van Haaren PM, Van Lanschot JJ, et al: Preoperative chemoradiation combined with regional hyperthermia for patients with resectable esophageal cancer. Int $\mathrm{J}$ Hyperthermia 25: 79-85, 2009. 